\title{
Effect of Using Bio and Mineral Fertilizers on Growth, Yield and Fruit Quality of Guava Cv. Seedy Montkhab
}

\author{
Wafaa, A.El-Sisy, Mervat, Sourour and Eman, El-Said ${ }^{1}$
}

\begin{abstract}
This work was conducted during 2007 \&2008 growing seasons on selected seedy guava trees (12 years old) grown in sandy soil in El-Maamoura zone in private farm. To study effect of mineral and bio nitrogen fertilizers comparing to traditional nitrogen fertilization on growth, flowering, fruit set \%, productivity and leaf and fruit mineral, total carbohydrates content and leaf total chlorophyll.
\end{abstract}

Data revealed that $T_{3}\left(2^{1 / 4} \mathrm{~kg}\right.$ amonium Sulphate $+1 \mathrm{~kg}$ super phosphate $+2 \mathrm{~kg}$ potassium Sulphate $+150 \mathrm{gm}$ nutrobine) significantly increased number of new shoots in both seasons of study while $T_{2}(3 \mathrm{~kg}$ amonium Sulphate +1 kg super phosphate $+2 \mathrm{~kg}$ potassium Sulphate $+75 \mathrm{gm}$ nutrobine), $T_{3}\left(2^{1 / 4} \mathrm{~kg}\right.$ amonium Sulphate $+1 \mathrm{~kg}$ super phosphate $+2 \mathrm{~kg}$ potassium Sulphate $+150 \mathrm{gm}$ nutrobine) $\mathrm{T}_{4}$ (1.5 kg amonium Sulphate $+1 \mathrm{~kg}$ super phosphate +2 kg potassium Sulphate +225 gm nutrobine) significant increased in average shoot length ,leaf total chlorophyll, number of flowers, number of fruits and fruit set \% in both seasons of study compared with control. $T_{4}$ gave the best result in yield of both seasons of study.

$\mathbf{T}_{3}, \mathbf{T}_{4}$ and $\mathbf{T}_{5}(3 / 4 \mathrm{~kg}$ amonium Sulphate $+1 \mathrm{~kg}$ super phosphate $+2 \mathrm{~kg}$ potassium Sulphate +300 gm nutrobine) increased fruit weight in first season only, while all treatments did not effected the fruit length, width and firmness in both seasons of study $T_{3}, T_{4}$ improved pulp thickness, while $T_{3}$ caused a significant increase in fruit T.S.S. in first season.

Fruit acidity was not affected with all treatments in both seasons of study. $T_{4}$ significantly increased V.C. content in both seasons of study.

$T_{2}, T_{3}$ and $T_{4}$ gave the highest concentration of $N$ content in leaves in both seasons while $T_{3}$ in first season and $T_{2}, T_{3}$ and $T_{4}$ in second season gave a significant increase in $P$ leaf content. All treatments increased leaf $K$ content in both seasons of study.

There was a significant increases in fruit nitrogen content with $T_{3}, T_{4}$ treatmenst due to application of biofertilizers in 2007 and 2008. While phosphorus and potassium contents were not affected with all treatments in both seasons of study.

Application of the combination of N.P.K. and nitrobein improved production and fruit quality of seedy guava. So, we can recommend using biofertilizers with decreasing mineral nitrogen $50-75 \%$ to save costs and keep environment unpolluted.

\section{INTRODUCTION}

The guava (psidium guajava, L.) trees grow well in most climates and in different kinds of soil and give good crops when the condition of soil is well (Bialy, 1960).

Guava is a vitamin C rich fruit and is very popular to the Egyptian consumer because of its suitable price.

The total guava area in A.R.E. is 39664 thousand feddans in 2007 and the annual production is approximately 330791 tons of guava fruits, according to statistics of the Ministry of Agriculture.

The efficiency of $\mathrm{N}$ fertilizer used in Egypt is very low due to the leaching of nitrate or ammonia volatilization from the nitrogen fertilizer (Soliman, 2001).

Moreover, using chemical fertilizer increased the environmental pollution.

Biofertilizers are biological preparation that contain primarily potent strains of microorganisms which are safe for human, animal and environment (Ahmed et al., 1997). They are capable of nitrogen fixation (RuizLozano et al., 1995) as well as enhancing availability of nutrients (Frankenberger and Arshad, 1995).

Using biofertilizers is one of the most particular interests to protect a groeco system and to achieve the sustainable agriculture (Herridge et al., 1994)

Biofertilitzers application sharing with little amount of chemical fertilizers proved to be efficient for increasing available nutrients besides improving growth and yield of cultivated crops (Abd El-Mouty et al., 2001 and Zaghloul, 2002).

The biofertilizer Nitrobine is produced by the Biofertilizers unit, ARC, Ministry of Agriculture and land Reclamation. Nitrobine contains Azotobacter chroococcum and Azospirllum barasilense on the same previous carrier (Shalan et al., 2001).

Nitrobine has greater amounts of bacteria which were responsible for fixation of nitrogen by atmosphere. Application of nitrobine achieved the following merits, decreasing the amount of mineral $\mathrm{N}$ by $25 \%$ and increasing the availability of various nutrients by plant (Subba-Rao, 1984).

\footnotetext{
${ }^{1}$ Horticulture research institute, A.R.C., Egypt

Received March 9, 2011, Accepted March 30, 2011
} 
Additionally, the use of biofertilizers increase growth and yield of several fruit trees (Haggag and Azzazy, 1996, Soliman, 2001, Abd El-Hameed, 2002, Osman, 2003, Youssif and Marzouk, 2005 and Abou Elkhashab et al., 2006).

This work was subjected to study the effect of nitrobine biofertilizers and different rates of nitrogen mineral fertilizer applied alone or in combinations on growth, leaf mineral content, yield and fruit quality of guava trees grown in sandy soil

\section{MATERIALS AND METHODS}

The present study was carried out during 2007 and 2008 seasons on 12 years old guava trees grown in sandy soil in El-Maamoura region east of Alexandria governorate in a private farm and spaced at $5 \times 5$ meters apart. Soil characters are listed in Table (1).

All trees in this orchard were annually fertilized with $20 \mathrm{~m}^{3} /$ feddan of organic manure in December, $1.5 \mathrm{~kg} /$ tree ammonium sulfate $(20.5 \% \mathrm{~N})$ in three equal doses in March, May and July, $1 \mathrm{~kg} /$ tree calcium super phosphate $\left(15.5 \% \mathrm{P}_{2} \mathrm{O}_{5}\right)$ in March and $2 \mathrm{~kg} /$ tree potassium sulphate $\left(48 \% \mathrm{~K}_{2} \mathrm{O}\right)$ in three doses, $1,1 / 2$ and $1 / 2 \mathrm{~kg}$, in March, May and July respectively. All trees received the same normal cultural practices commonly adopted in this orchard.

The selected trees were nearly similar in vigor and free from any pathogens. The trees received the different treatments in two seasons as follows:

$\mathrm{T}_{1}$-control: $1 \frac{1}{2} \mathrm{~kg}$ ammonium sulphate $+1 \mathrm{~kg}$ super phosphate $+2 \mathrm{~kg}$ potassium sulphate

$\mathrm{T}_{2}: 3 \mathrm{~kg}$ ammonium sulphate $+1 \mathrm{~kg}$ super phosphate +2 $\mathrm{kg}$ potassium sulphate $+75 \mathrm{gm}$ Nitrobine

$\mathrm{T}_{3}: 2 \frac{1}{4} \mathrm{~kg}$ amonium sulphate $+1 \mathrm{~kg}$ super phosphate +2 $\mathrm{kg}$ potassium sulphate $+150 \mathrm{gm}$ Nitrobine

$\mathrm{T}_{4}: 1 \frac{1}{2} \mathrm{~kg}$ amonium sulphate $+1 \mathrm{~kg}$ super phosphate +2 $\mathrm{kg}$ potassium sulphate $+225 \mathrm{gm}$ Nitrobine

$\mathrm{T}_{5}: 3 / 4 \mathrm{~kg}$ amonium sulphate $+1 \mathrm{~kg}$ super phosphate +2

$\mathrm{kg}$ potassium sulphate $+300 \mathrm{gm}$ Nitrobine

$\mathrm{T}_{6}: 0 \mathrm{~kg}$ amonium sulphate $+1 \mathrm{~kg}$ super phosphate +2

$\mathrm{kg}$ potassium sulphate $+450 \mathrm{gm}$ Nitrobine

Amonium sulphate and Nitrobine divided into 3 equal doses were applied in March, May and July while super phosphate was applied in March. Potassium sulphate was applied in three doses $1,1 / 2$ and $1 / 2 \mathrm{~kg}$ in March, May and July respectively.

Eighteen trees as uniform as possible were selected for the present study. The treatments were applied and arranged in a randomized complete block design with guard trees, each treatment included three replicates. The following parameters were determined in the two successive growth seasons including number of new shoots/ tree, average shoot length $(\mathrm{cm}$.), average leaf area $\left(\mathrm{cm}^{2}\right.$.), total chlorophyll in leaf, number of flowers, number of fruits, fruits set $\%$ and yield $(\mathrm{kg} /$ tree $)$. Fruit and leaf NPK contents were determined.

At the middle of August of both seasons, sample of 20leaves per tree were taken at fixed position on shoots of each tree and washed with tap water and rinsed with distilled water and oven dried at $70^{\circ} \mathrm{c}$ to constant weight and then ground.

At the harvesting time, (first of September) fruit sample consisting of six fruits per replicate were taken at random for physical \& chemical analysis.

Quality of guava fruit included, fruit weight, length, width, firmness, pulp thickness, total soluble solids, acidity, vitamin $\mathrm{C}$ and total carbohydrates.

Fruit firmness was determined by Magness and Taylor (1925) pressure tester using a5/16" plunger. Two readings were taken at two different positions on the flesh of each fruit after peeling.

Fruit juice acidity and vitamin C content were determined according to the (A.O.A.C. 1980), percentage of total soluble solids in juice was determined by a hand referectometer. The fresh material of each sample was prepared for determination of total carbohydrates according to Herbert et al. (1971).

The samples were washed with tap water and oven dried at $70^{\circ} \mathrm{c}$ to constant weight then ground. The ground samples of leaves and fruits were digested with sulphoric acid and hydrogen peroxide according to Evenhuis and Dewaard (1980).N and P leaf and fruit contents were colorimetrically determined according to Evenhuis (1976) and Murphy and Riley (1962), respectively. $\mathrm{K}$ content was determined against a standard by flame photometer.

At the end of experimental season the total chlorophyll was measured in leaves by using Minolta Chlorophyll

\section{Table 1. Physical and Chemical analysis of the experimental soil}

\begin{tabular}{ccccccccccc}
\hline \multirow{2}{*}{ Soil depth } & \multirow{2}{*}{$\mathbf{p H}$} & $\begin{array}{c}\text { E.C } \\
\mathbf{d S} / \mathbf{m}\end{array}$ & \multicolumn{3}{c}{ Soluble cation $\mathbf{~ m g / 1 l i t e r}$} & \multicolumn{3}{c}{ Soluble anion Meq/1litre } \\
\hline & & & $\mathbf{N a}^{+}$ & $\mathbf{K}^{+}$ & $\mathbf{C a}^{++}$ & $\mathbf{M g}^{++}$ & $\mathbf{S O}_{\mathbf{4}}^{--}$ & $\mathbf{C L}^{-}$ & $\mathbf{H C O}_{\mathbf{3}}^{-}$ & $\mathbf{C O}_{\mathbf{3}}^{-}$ \\
\hline $0-30$ & 7.74 & 1.09 & 3.91 & 0.31 & 3.2 & 1.8 & 2.9 & 7.00 & 1.00 & $----^{--}$ \\
\hline $30-60$ & 7.94 & 0.54 & 1.73 & 0.56 & 1.6 & 1.2 & 2.4 & 2.00 & 1.00 & ----- \\
\hline
\end{tabular}


Meter PAD-502 Minolta camera LTD, Japan according to the method described by Yadava (1988).

Data were statistically analyzed according to Snedecor and Cochram (1990) and L.S.D. test at 0.05 levels was used for comparison between treatments.

\section{RESULTS AND DISCUSSIONS}

\section{A. Vegetative growth parameters:}

\section{A-1- Number of new shoots/ tree:}

The data in (Table2) indicated that, all fertilizer treatments (mineral + biofertilizers), significantly increased the number of new shoots/tree as compared with control except $\mathrm{T}_{6}$ in first season. This promoting effect on number of new shoots could be due to the increase in total nitrogen fixation and availability in the soil (Rodriguez and Fraga, 1999).

\section{A-2- Average shoot length:}

Concerning the effect of fertilization treatments on average shoot length, the obtained results in (Table 2) indicated that, $\mathrm{T}_{2}, \mathrm{~T}_{3}$ and $\mathrm{T}_{4}$ treatments gave a significant increase in average shoot length in both seasons 2007 and 2008. On the other hand $T_{5}$ and $T_{6}$ gave no significant effect in both seasons of study.

The increase in plant growth may be attributed to the capability of micro organisms in biofertilizers to produce growth regulators such as auxins, cytokinins and gibberellins which affect growth and nutrient uptake (Soliman, 2001).

These results are in agreement with those obtained by Abou-Taleb et al. (2004) on olive, Fatma- Mahmoud (1999) on peach and Abou El-Khashab et al. (2006) on guava.

\section{A-3-Average leaf area:}

The data presented in (Table 2) showed that, there were no significant differences in the average leaf area among all fertilization treatments in both seasons of study.

The present results are partially in line with those reported by Mahmoud and Mahmoud (1999) on peach, Reddy et al. (2003) on mulberry, El. Sayed (2002) on Flame seedless grape and El- Sharkawy and Mehaisen (2005) on guava. They all found that, the microbial fertilization led to improvement in plant vigor and they added nitrogen fixing bacterium led to great promotion in all measured vegetative parameters such as leaf area, plant height, leaf number, shoot growth and shoot length.

\section{B. Total leaf chlorophyll:}

Data in (Table2), showed that, the total leaf chlorophyll values in trees of the applied treatments were significantly increased when compared with the control in both seasons of study.

These results are in harmony with those report of Ezz and Nawar(1994) which concluded that, inoculation of sour orange seedlings with mycorrhizal fungi increased total chlorophyll in first season of trial and chlorophyll in the second season. Also Ibrahim et al. (2005) contended that, biofertilization increased leaf chlorophyll content of canino apricot. Moreover Reddy et al. (2003) on mulberry varieties, Abou El-Khashab (2003) in olive seedlings C.V. (picual) and (El.Naggar and Ramzy, 2005) on Narcissus tazetta (2005) came to the same findings

So, the superiority of microbial biofertilization treatments in increase chlorophyll leaf content could be attributed to the influence of nitrogen fixers bacteria Gabr and Nour El-Dein (2005).

\section{C- Flowering and yield:}

\section{C-1- No. of flowers/ tree}

The data in Table 3 showed that, all treatments significantly increased the number of flowers per tree in both seasons of study except the $6^{\text {th }}$ treatment in the second season which cause a slight increase compared with control treatment.

The improvement of flowering measurements resulted by biofertilizers application may be attributed to the stimulating effect of the absorbed nutrients on photosynthesis process which certainly reflected positively on measurements of both flowering and fruiting

\section{C-2-Fruit set \%:}

Fruit set $\%$ was not affected by any of the studied treatments in both seasons of study.

\section{C-3- Yield/ tree:}

The values of yield per tree either number of fruits or $\mathrm{kg} /$ tree are shown in Table (3). The $4^{\text {th }}$ treatment gave the highest values of yield in both seasons of study while the smallest values was observed in control $\left(\mathrm{T}_{1}\right)$. Similar results were consistent with (Youssef et al., 2001), (Zaghloul, 2002), (Akl et al., 1997) and (Mansour, 1998) they reported that biofertilizers such as phosphorien, active dry yeast and nitrobine were very effective in improving the yield. 
Table2. Effect of using chemical and bio fertilizers on Vegetative growth in 2007-2008

\begin{tabular}{|c|c|c|c|c|c|c|c|c|}
\hline \multirow[t]{2}{*}{ Treatments } & \multicolumn{2}{|c|}{$\begin{array}{c}\text { No. of new shoots } \\
\text { per tree }\end{array}$} & \multicolumn{2}{|c|}{$\begin{array}{l}\text { Average shoot } \\
\text { length }(\mathrm{cm})\end{array}$} & \multicolumn{2}{|c|}{$\begin{array}{l}\text { Average leaf area } \\
\mathrm{cm}^{2}\end{array}$} & \multicolumn{2}{|c|}{$\begin{array}{l}\text { Total leaf chlorophyll } \\
\left(\mathrm{mg} / 100 \mathrm{~cm}^{2}\right)\end{array}$} \\
\hline & 2007 & 2008 & 2007 & 2008 & 2007 & 2008 & 2007 & 2008 \\
\hline $\mathbf{T}_{1}$ & 728.3 & 843.3 & 30.443 & 33.067 & 45.897 & 49.807 & 39.330 & 37.213 \\
\hline $\mathbf{T}_{2}$ & 1490.0 & 1780.0 & 39.800 & 52.090 & 49.920 & 47.470 & 44.410 & 43.283 \\
\hline $\mathbf{T}_{3}$ & 1891.7 & 2470.0 & 41.420 & 48.337 & 45.960 & 53.377 & 48.103 & 48.220 \\
\hline $\mathbf{T}_{4}$ & 1619.0 & 2220.0 & 38.957 & 47.047 & 46.253 & 51.733 & 49.683 & 45.597 \\
\hline $\mathbf{T}_{5}$ & 1438.7 & 1690.0 & 35.08 & 42.513 & 46.410 & 50.953 & 48.743 & 44.550 \\
\hline$T_{6}$ & 1240.0 & 1512.0 & 30.767 & 41.287 & 45.013 & 41.997 & 46.670 & 43.167 \\
\hline $\begin{array}{ll}\text { L.S.D } & 0.05 \\
\end{array}$ & 672.46 & 520.54 & 8.497 & 10.297 & 7.831 & 12.729 & 4.291 & 5.944 \\
\hline
\end{tabular}

Table 3. Effect of using chemical and bio fertilizers or number of fruit/ tree, number of flowers/ tree, fruit set \% / tree and yield $\mathrm{kg} /$ tree

\begin{tabular}{|c|c|c|c|c|c|c|c|c|}
\hline \multirow[t]{2}{*}{ Treatments } & \multicolumn{2}{|c|}{$\begin{array}{l}\text { Number of } \\
\text { flowers/tree }\end{array}$} & \multicolumn{2}{|c|}{ Fruit set \% } & \multicolumn{2}{|c|}{$\begin{array}{l}\text { Number of } \\
\text { fruits/tree }\end{array}$} & \multicolumn{2}{|c|}{ Yield kg/tree } \\
\hline & 2007 & 2008 & 2007 & 2008 & 2007 & 2008 & 2007 & 2008 \\
\hline $\mathbf{T}_{1}$ & 251.33 & 295.00 & 75.290 & 70.403 & 188.33 & 208.67 & 22.95 & 29.214 \\
\hline $\mathbf{T}_{2}$ & 340.00 & 375.00 & 76.15 & 78.953 & 259.00 & 295.33 & 31.227 & 42.232 \\
\hline $\mathbf{T}_{3}$ & 384.67 & 441.00 & 76.557 & 77.697 & 294.00 & 343.67 & 36.926 & 51.626 \\
\hline $\mathbf{T}_{4}$ & 412.67 & 488.67 & 82.303 & 82.373 & 339.67 & 385.00 & 48.402 & 66.732 \\
\hline $\mathbf{T}_{5}$ & 392.00 & 443.33 & 80.263 & 79.633 & 314.00 & 348.67 & 34.672 & 56.788 \\
\hline$T_{6}$ & 367.33 & 317.67 & 71.157 & 76.713 & 291.33 & 243.67 & 32.603 & 40.157 \\
\hline L.S.D $\quad 0.05$ & 35.3 & 77.606 & 6.1902 & 4.4075 & 29.141 & 54.975 & 11.387 & 8.2323 \\
\hline
\end{tabular}

The improvement of flowering and fruit set $\%$ as affected by biofertilizers were noticied with Akl et al. (1997), Zaghloul (2002), Abou-Taleb et al. (2004) and Abou El-Kashab et al. (2006) in guava. They reported that, biofertilizers such as phosphorene and nitrobrein improved flowering and fruit set percentage of fruit trees.

The improving of the yield of guava fruits may be attributed to the increase in average fruit weight (Mansour, 1998) on apple and (Osman 2003) on zaghloul date palm, or may be due to the increase in amino acids content which are considered as a constituent of protein and other compounds that share in development of new tissues (Trawry et al., 1999) and Smith (1998)

NPK+biofertilizers increased cell division and enlargement and consequently increased vegetative growth which reflected on yield (Abd El-Naby, 2000) and (Moustafa 2002).

Many investigators referred to the promotion which occurred in growth due to application of biofertilizers ( $\mathrm{N}_{2}$-fixers) as a result of its effect on increasing the availability of $\mathrm{N}$-fixed and the higher $\mathrm{N}$ - uptaken by plants (Subbn Rao 1984).

These results are in agreement with those obtained by (Akl et al., 1997) and (Mansour, 1998) who reported that, biofertilizers as nitroben were very effective in improving the yield. In addition (Gomez and Munoz, 1998) stated that, biofertilizers did not totally replace mineral fertilization, but they significantly reduce their rates of application.

\section{D- Fruit characteristics:}

\section{A- Physical characteristics:}

Concerning the effect of treatments on fruit physical properties, the obtained data are listed in Table (5), indicated that the highest value of fruit weight (gm) was found in $T_{3}$ and $T_{4}$ in first and second seasons, without significant differences when compared with control.

In both seasons of study, all treatments did not significantly effect fruit length $(\mathrm{cm})$, fruit width $(\mathrm{cm})$ and fruit firmness. These results were in line with those obtained by (Yousif and Marzouk, 2005) on guava. They found that fruit length, diameter and firmness were not affected by mineral and biofertilizers.

\section{B- Fruit pulp thickness:}

Fruit pulp thickness increased in $3^{\text {rd }}$ and $4^{\text {th }}$ treatments in both seasons of study compared with control (Table 4). These results were in agreement with Abou EL-Kashab et al. (2006) on guava they reported that, nitrobein + phosphorin increased significantly fruit pulp thickness. 
Table 4. Fruit chemical properties in 2007and 2008

\begin{tabular}{|c|c|c|c|c|c|c|c|c|}
\hline \multirow{2}{*}{ Treatments } & \multicolumn{2}{|c|}{$\begin{array}{c}\text { Fruit pulp } \\
\text { thickness }\end{array}$} & \multicolumn{2}{|c|}{ T.S.S (\%) } & \multicolumn{2}{|c|}{ Acidity (\%) } & \multicolumn{2}{|c|}{$\begin{array}{c}\text { V.C. } \\
(\mathrm{mg} / 100 \mathrm{gm} \text { flesh })\end{array}$} \\
\hline & 2007 & 2008 & 2007 & 2008 & 2007 & 2008 & 2007 & 2008 \\
\hline $\mathbf{T}_{1}$ & 0.905 & 1.103 & 5.700 & 6.1667 & 1.063 & 1.181 & 28.583 & 35.730 \\
\hline$T_{2}$ & 1.083 & 1.396 & 6.200 & 6.500 & 0.922 & 0.872 & 39.410 & 45.777 \\
\hline$T_{3}$ & 1.356 & 1.520 & 6.800 & 7.8667 & 0.922 & 0.927 & 37.227 & 53.977 \\
\hline $\mathbf{T}_{4}$ & 1.661 & 1.536 & 7.1667 & 7.700 & 0.998 & 1.014 & 40.340 & 59.240 \\
\hline$T_{5}$ & 1.130 & 1.496 & 6.3667 & 6.7000 & 0.972 & 0.962 & 36.263 & 53.997 \\
\hline$T_{6}$ & 1.033 & 1.370 & 6.300 & 6.9000 & 1.101 & 1.126 & 28.767 & 44.247 \\
\hline \begin{tabular}{ll|} 
L.S.D & 0.05 \\
\end{tabular} & 0.4044 & 0.4106 & 0.7978 & 0.932 & 0.430 & 0.349 & 4.6013 & 7.3568 \\
\hline
\end{tabular}

Table 5. Effect of using bio and mineral fertilizers on fruit weight, length, width and fruit firmness in 2007 and 2008 seasons

\begin{tabular}{|c|c|c|c|c|c|c|c|c|}
\hline \multirow{2}{*}{$\begin{array}{l}\text { Treatment per } \\
\text { tree per year }\end{array}$} & \multicolumn{2}{|c|}{$\begin{array}{l}\text { Fruit weight } \\
\text { (gm) }\end{array}$} & \multicolumn{2}{|c|}{$\begin{array}{c}\text { Fruit length } \\
\text { (cm) }\end{array}$} & \multicolumn{2}{|c|}{$\begin{array}{l}\text { Fruit width } \\
(\mathbf{c m})\end{array}$} & \multicolumn{2}{|c|}{$\begin{array}{l}\text { Fruit firmness } \\
\left(1 \mathrm{~b} / \mathbf{i n}^{2}\right)\end{array}$} \\
\hline & 2007 & 2008 & 2007 & 2008 & 2007 & 2008 & 2007 & 2008 \\
\hline$T_{1}$ & 121.87 & 140.0 & 7.15 & 7.50 & 5.85 & 5.87 & 2.836 & 3.758 \\
\hline $\mathbf{T}_{2}$ & 120.57 & 143.00 & 7.83 & 8.85 & 6.52 & 5.86 & 2.220 & 3.110 \\
\hline $\mathbf{T}_{3}$ & 125.6 & 150.22 & 8.43 & 9.55 & 6.08 & 6.46 & 3.066 & 3.133 \\
\hline $\mathbf{T}_{4}$ & 142.50 & 173.33 & 8.06 & 9.04 & 5.52 & 6.29 & 2.766 & 4.010 \\
\hline $\mathbf{T}_{5}$ & 110.42 & 162.87 & 7.67 & 8.90 & 5.76 & 5.06 & 2.333 & 3.650 \\
\hline$T_{6}$ & 111.91 & 164.80 & 7.85 & 8.83 & 5.86 & 6.57 & 2.766 & 4.660 \\
\hline $\begin{array}{ll}\text { L.S.D } & 0.05\end{array}$ & 28.288 & 25.069 & 1.594 & 2.0714 & 0.7515 & 0.7732 & 1.4478 & 2.140 \\
\hline
\end{tabular}

\section{E- Fruit chemical properties:}

\section{E-1- Total soluble solids (T.S.S):}

Total Soluble Solids content of juice was increased due to the treatment $3^{\text {rd }}$ in first season and treatment $3^{\text {rd }}$ and treatment $4^{\text {th }}$ in second season comparing with control (Table 4).

Yousif and Marzouk (2005) on guava reported that applying $75 \%$ mineral fertilizer+ biofertilizers significantly increased T.S.S content. On the other hand Abou El-Kashab et al. (2006) reported that, nitrobien+ phosphorien reduced significantly T.S.S content in guava and was positively affected by NPK+ Potaseine fertilization.

\section{E-2- Acidity:}

No significant differences were noticed for acidity between all treatments in both seasons of study (Table 4). However, Abo El-Kashab et al. (2006), found that combination of nitrobien+ potaseine treatments on guava increased significantly the acidity\%.

\section{E-3- V.C content:}

The data in Table (4) showed that, the $\mathrm{T}_{4}$ gave the highest values of V.C (mg/100ml juice) in both seasons of study with significantly differences comparing with control. These results are partially agreement with those obtained by Yousif and Marzouk (2005) on guava, Mansour (1998) on apple. They found that V.C content was significantly increased with biofertilizers. Meanwhile Abou El-Kashab et al. (2006) on guava reported that vitamin $\mathrm{C}$ was not influenced with any treatment of mineral+ biofertilizers.

\section{F- Leaf mineral contents:}

The data representing the effect of mineral and bionitrogen fertilization on leaf mineral content of guava trees are shown in Table (6).

\section{F-1- Nitrogen:}

The results showed that $T_{2}, T_{3} \& T_{4}$ significantly increased leaf nitrogen content in both seasons of study.

These results are in line with those obtained by ElSayed (2002), Abd El-Hameed (2002), Abou-Taleb et al. (2004) on olive, Yousif and Marzouk (2005) on guava and Abou El-Khasab et al. (2006) on guava. They concluded that microbial biofertilizers increased leaf $\mathrm{N}$ content because nitrogen fixers rhizobacteria and $\mathrm{AM}$ fungi had a vital role in improving $\mathrm{N}_{2}$ fixation processes.

Also $\mathrm{T}_{5} \& \mathrm{~T}_{6}$ in both seasons of study did not show a significant effect on leaf nitrogen content. These results may be due to the lack of nitrogen which was applied in low amount in mineral form.

\section{F-2- Phosphorus:}

The results showed that $T_{4}$ in the first season and $T_{2}$ $, T_{3}, T_{4}$ in the second season gave significant increase in leaf phosphorus content. These findings are in agreement with those found by Frankenberg and Arshad (1995), Abd El-Hameed (2002), Abou-Taleb et al. (2004), Abou El-Khasab et al. (2005) and Gaber and Nour El-Dien (2005). They reported that 
Table 6. Effect of using bio and chemical fertilizers on guava leaf mineral content $\mathrm{N}, \mathrm{P}, \mathrm{K}$ and total carbohydrates in 2007 and 2008 seasons

\begin{tabular}{|c|c|c|c|c|c|c|c|c|}
\hline \multirow{2}{*}{ Treatments } & \multicolumn{2}{|c|}{ N\% } & \multicolumn{2}{|c|}{$\mathbf{P} \%$} & \multicolumn{2}{|c|}{ K \% } & \multicolumn{2}{|c|}{ Total carbohydrates } \\
\hline & 2007 & 2008 & 2007 & 2008 & 2007 & 2008 & 2007 & 2008 \\
\hline$T_{1}$ & 1.733 & 1.956 & 0.773 & 0.713 & 0.938 & 0.796 & 6.980 & 7.040 \\
\hline $\mathbf{T}_{2}$ & 2.200 & 2.2667 & 0.760 & 0.816 & 1.660 & 1.276 & 7.483 & 8.056 \\
\hline $\mathbf{T}_{3}$ & 1.933 & 2.220 & 0.823 & 0.906 & 2.560 & 2.446 & 8.320 & 8.006 \\
\hline $\mathbf{T}_{4}$ & 1.966 & 2.266 & 1.046 & 1.086 & 1.930 & 1.473 & 7.860 & 7.833 \\
\hline $\mathbf{T}_{5}$ & 1.890 & 2.137 & 0.873 & 0.866 & 1.640 & 2.133 & 8.246 & 7.843 \\
\hline$T_{6}$ & 1.400 & 2.130 & 0.766 & 0.676 & 1.400 & 1.466 & 7.873 & 8.346 \\
\hline $\begin{array}{|ll|}\text { L.S.D } & \mathbf{0 . 0 5} \\
\end{array}$ & 0.2086 & 0.2278 & 0.1193 & 0.0829 & 0.6977 & 0.3857 & 0.6713 & 0.4409 \\
\hline
\end{tabular}

Table 7. Effect of using bio and chemical fertilizers on guava fruit mineral content $\mathrm{N}, \mathrm{P}, \mathrm{K}$ and total carbohydrates in 2007 and 2008 seasons

\begin{tabular}{|c|c|c|c|c|c|c|c|c|}
\hline \multirow{2}{*}{ Treatments } & \multicolumn{2}{|c|}{$\mathbf{N} \%$} & \multicolumn{2}{|c|}{$\mathbf{P} \%$} & \multicolumn{2}{|c|}{ K \% } & \multicolumn{2}{|c|}{ Total carbohydrate } \\
\hline & 2007 & 2008 & 2007 & 2008 & 2007 & 2008 & 2007 & 2008 \\
\hline$T_{1}$ & 1.433 & 1.666 & 0.656 & 0.683 & 1.017 & 1.076 & 11.626 & 11.660 \\
\hline $\mathbf{T}_{2}$ & 1.900 & 2.033 & 0.670 & 0.656 & 1.300 & 1.766 & 12.653 & 13.600 \\
\hline $\mathbf{T}_{3}$ & 1.766 & 2.00 & 0.686 & 0.816 & 1.160 & 1.386 & 13.256 & 14.980 \\
\hline $\mathbf{T}_{4}$ & 1.633 & 1.833 & 0.650 & 0.726 & 1.310 & 1.613 & 13.746 & 14.900 \\
\hline $\mathbf{T}_{5}$ & 1.166 & 1.730 & 0.760 & 0.670 & 1.410 & 1.326 & 14.043 & 14.063 \\
\hline$T_{6}$ & 1.250 & 1.500 & 0.756 & 0.610 & 1.353 & 1.400 & 16.166 & 12.980 \\
\hline L.S.D 0.05 & 0.1778 & 0.2772 & 0.1073 & 0.087 & 0.3993 & 0.485 & 1.0764 & 1.2854 \\
\hline
\end{tabular}

biofertilizer can increase phosphorous leaf content, this may be due to the bacteria present in the biofertilizers which secretes promoting substances or organic acid that enhance nutrient uptake. In addition, using rhizobacteria may have released phosphate ions which may be effectively taken up through the external arbuscular mycorrhiza mycelium.

\section{F-3- Potassium:}

It was appeared that all treatments significantly increased potassium content in leaf except $T_{6}$ in first season which gave the lowest value of $\mathrm{K}$ content.

These results are in line with those obtained by ElSayed (2002), El-Sharkawy and Mehasen (2005) on guava, Abou El-Khasab (2005) on guava and Gabr and Nour El-Dien (2005) on Anna apple. They concluded that biofertilizers increased $\mathrm{K}$ content of leaves.

\section{G- Fruit mineral content:}

\section{G-1-Nitrogen:}

The data presented in Table 7 showed that $\mathrm{T}_{2}, \mathrm{~T}_{3}$ and $\mathrm{T}_{4}$ in both seasons of study significantly increased fruit nitrogen content.

\section{G-2-Phosphorus:}

The data showed that all treatments except $T_{3}$ in second season did not affect fruit phosphorus content.

\section{G-3-potassium:}

No significant differences were obtained in fruit potassium content in both seasons of study as compared with control.

We can attribute that increasing fruit mineral contents may be due to the increasing of nutrient uptake.

\section{H-Total carbohydrates:}

Data in Tables 6 and 7 indicated that all treatments except $T_{2}$ in the first season significantly increased the total carbohydrates of guava leaves and fruits in both seasons of study.

The obtained results are in agreement with those concluded by Ezz and Nawar (1994), they reported that mycorrhizal inoculation of sour orange seedlings increased leaf and root sugars and carbohydrates concentration in comparison with non infected control. Mycorrhizal colonization increased rate of photosynthesis of sour orange. Mostafa (2002) and Abd El-Monem and Radwan (2003) reported that the biofertilizer play a role in increasing the metabolism processes which reflects on carbohydrates and other compounds.

Gabr and Nour El-Dien (2005) on apple reported that biofertilizers significantly increased Anna apple leaf content of all studied carbohydrates determinations, 
and this may due to increasing the rate of photosynthesis process.

In conclusion, we can say that the combination between mineral nitrogen fertilizers and biofertilizer (nitrobien) improved growth, flowering, and fruit set $\%$, fruit quality and yield.

\section{REFERENCES}

A.O.A.C. (1980). Official methods and tentative methods of analysis. $13^{\text {th }}$ ed. Washington D.C.U.S.A.

Abd El-Hameed, A.A. (2002). Response of Manzanillo olive trees to nitrogen and biofertilizer under North. Western Coast conditions. M.Sc Thesis, Fac. Agric. Cairo Univ., Egypt pp 84-88.

Abd El-Monem, A.A. Eman and S.M.A. Radwan (2003) Response of 'Williams' banana plants to biofertilization in relations to growth productivity and fruit quality. Arab Univ., J. Agric. Sci. Ain Shams Univ., Cairo, 11(2): 751763.

Abd El-Naby, S.K.M (2000). Effect of banana compost as organic manure on growth, nutrients status, yield and fruit quality of Maghrabi banana Asuit. J. Agric .Sci., (3): 101114, Egypt.

Abdel-Mouty, Mona. M, Ali, Aisha, H. and Rizk, Fatma, A. (2001). Potato yield as affected by the interaction between bio-and organic fertilizers. Egypt J. Appl. 16 (6) 287.

Abou-Elkhashab, A.M (2003).Growth and chemical constituents of some olive cultivates as affected by biofertilizers and different water regimes. Egypt j. Agric. Res. 1:243-265.

Abou-Elkhasab, A.M. Essa, K.B and EL-Iragy, M.A. (2006). Winter guava trees as affected by NPK, Nitrobein, Phosphoene and potasiene. Alex, J. Agric. Res. (51) 8593(special ISSUE 2006).

Abou-Taleb, A. Sofia, A.M. Abou El-Khashab and S.T. Wafaa (2004). Growth and productivity of olive trees as affected by some bio and mineral nitrogen fertilizers. Minufiya J. Agric. Res. Egypt. 29 (4): 933-963.

Ahmed, F.F., A.M. AKL, F.M. EL-Morsy and M.A. Ragab (1997).The beneficial effects of biofertilizers on Red Roomy grapevines (vitis vinifera L.).1-The effect on growth and vine nutritional status. Ann. Agnic. Sci. Moshtohor, 35(1): 489-495.

AKL, A.M., F.F. Ahmed, F.M Elmorsy and M.A. Ragab. (1997).The beneficial effect of biofertilizers on "Red Roumi" grape vines (Vitis vineferal) 11-the effect on berry set,yield and quality of berries. Annual. J. Agric. Sci. Moshtohor, 35: (1) 497-502.

Bialy, L.H. (1960). Manual of cultivated plants. The Macmilan Company. New York, U.S.A. pp.1116.

El-Naggar A.A.M. and Ramzy M.R. Hedia (2005). Effect of interaction between biofertilizers and organic or minerals fertilizers on soil oc, NPK availability and production of Narcissus tazetta, H. Alex. J. Agric. Res. 50(1): 143-157.
El-Sayed H.A. (2002). Attempts for stimulating the availability of phosphorus in triple calcium super phosphate for Flame vines by using some materials. Annals of Agric Sci. Moshtohor, Vol. 40 (1): 2403-2414.

El-Sharkawy, Sh. M.M. and S.M.A. Mehaisen (2005). Response of guava trees to biofertilization Minufiyha. J. Agric. Res. 30(2): 673-688.

Evenhuis, B. and P.W. Dewaard (1980). Principals and practices in plant analysis. F.A.O. Soil Bull, 39 (1) : 152162.

Evenhuis.B.(1976). Nitrogen determination Dept. Agric. Res. Royal. Tropical Inst. Amesterdam.

Ezz. T and A. Nawar (1994). Salinity and mycorrhizal association in relation to carbohydrate status, leaf chlorophyll and polyphenal oxidases enzymes in sour orange seedlings. Alex. J. of Agric. Res. 39 (1) : 263-280.

Frankenberger, W.T. and M.J.R. Arshad (1995). Phytohormones in soil (microbial production and function). Marcel Dekker, Inc publishers, 270 Madison Avenue. New York .U.S.A cited from Yousif and Marzouk (2005).

Gaber. M.A and M. Nour El-Dein (2005). Effect of microbial biofertilization on reducing chemical fertilizers, vegetative growth, nutritional status, yield and fruit quality of apple. Alex. j. Agric. Res. 50 (3): 121-129.

Gomez. R. and H.A. Munoz (1998). Biofertilization of garlic (Allium sativum, L.) on a compacted red ferralitic soil. Cultivars Tropicales, 19(2): 9-13.

Haggag, L.F. and A.M.A. Azzazy (1996). Evaluation of microbein as a multi-strains biofertilizer for production of improved mango seedlings with appropriate vigour for garafting in shorter time. Annals Agric Sci Ain shams Univ. Cairo 41:321-331.

Herbert, D., P.J. Phipps and R.E. Strange (1971). Determination of total carbohydrates. Methods in microbial 5: 209-344.

Herridge, D.F, O.P. Rupela, R. Serraj, D.P.Beck (1994). Screening techniques and improved biological nitrogen fixation and improved season food legumes, Euphytica 73: 95-108. Cited from Abo-Elkashab et al. (2006).

Ibrahim H.K., G.S. Abd El-Latif and A.A. Khalil (2005). Effect of soil application of different treatments on growth, fruiting parameters, fruit properties and leaf nutrient of canino apricot trees, J. Agric. Sci. Mansoura. Univ. 30(3) 1617-1629.

Magness, J.P. and Taylor G.F. (1925). An improved type pressure tests for the determination of fruit maturity. U.S. Dep. Agric. Cairo 350,8.PP.

Mahmoud, H.M and Fatma A.F. Mahmoud (1999). Studies on effect of some biofertilizers on growth of peach seedlings and root rot disease incidences. Egypt. J. Hort. 26, (1): 718.

Mansour, A.E.M. (1998). Response of Anna apples to some biofertilizers. Egypt. J .Hort., 25(2): 241-251. 
Mostafa, M.M. (2002). Effect of biofertilizer, salinity and magnetic technique on the growth of some annual plants. Alex. J. Agric. Res. 47(2):151-162.

Moustafa, H. Magda (2002). Studies on fertilization of Washington navel orange trees. PP.61-68. Ph.D. Thesis. Faculty of Agric Moshtomor, Zagazig Univ., Egypt.

Murphy, J. and P. Riley (1962). A modified single solution method for the determination of phosphorus in natural water. Anal. Chem. Acta 27: 13-36.

Osman, S.M. (2003). Effect of biofertilization of fruit physiological and chemical properties of Zaghlol date palm. Annals Agric. Sci. Ain Shams Univ. Cairo, 48(1) : 297-305.

Reddy, P.S., T.V. Rao, S.S. Venkataramana and P. Suryanarayana (2003). Response of mulberry varieties to VAM and Azotobacter, Indian J. Plant Physiol. 8: 171174.

Rodriguez, H. and R. Fraga (1999). Phosphate solubilizing bacteria and their role in plant growth promotion. Biotechnology Advances 17: 319-339.

Ruiz-Lozano, J.M., R. Azcon and M. Gomez (1995). Effect of arbuscular mycorrhizal glomus specie on drought tolerance: Physiological and nutrional plant responses. Apple-Environment Microbial. Bull Monthly by Am. Soc. for Microbial, 16 (2): 456-460.

Shalan, M.N, T.A. Abd El-Latif, S.G.I. Soliman and E.O. ElGaawad (2001). Effect of some chemical and biofertilizer treatments on rosella (Hibiscus sabdoriffa, h.) plants. Egypt. J. Agric. Res. 79: 587-606.

Smith, B.L. (1998). Microorganisms in soil benefit growth and yield of banana Nitropika Bullutien, (299): 22-25.

Snedecor, G.W and W.G. Cochran (1990). Statistical methods $1^{\text {th }}$ ed. The lowa. State. Univ., Press. Ames. Iowa. U.S.A P.593.

Soliman, G. Mona (2001). Response of banana and guava plants to some biological and minerals fertilizers. MSc. Thesis. Fac. Agrie. Alex. Univ., Egypt.
Subba-Rao, N.S. (1984). Biofertilizers in Agriculture, Oxford IBH. Company New Delhi, PP. 1-786. Cited from Sourour, Response of Picual olive trees to minerals and bio-nitrogen fertilization. J. Adv. Agric. Res. (Fac. Agri. Saba Basha Vol. 13(4): 2008, 647).

Trawry, D.k.; M.A. Hassan and P.K. Chattopadhyay (1999). Leaf nutrient and chlorophyll content in banana (Musa AAA.) under the influence of Azotobacter and Azospirillum inoculation. Enviorn and Ecol .J. 17(2): 346350.

Yadava, U.L. (1988). A rapid and non destructors method to determine chlorophyll in intact leaves. Hort. Science. 21.1449 .

Yousif, A.M. and H.A. Marzouk (2005). Comparative studies of using mineral and bio-fertilizers on growth and yield of guava. J. Adv. Agric Res. Fac. Agric. (Saba Basha). Alex. Univ. 10(3): 283-293

Youssef, A.M., EL-Fouly A.M., Youssef M.S and Mohamedien, S.A.(2001). Effect of using organic fertilizers in ferigation system on yield and fruit quality of tomato. Egypt J. Hort. 28, No.(1): 59-77.

Zaghloul, R.A (2002). Biofertilizeration and organic manuring efficiency on growth and yield of potato plants (Sopanum tubersom, L.). Rec. Technologiesm Agic. Proc. of the Second Congress. Vol. (1): 79-90.

Yousif, A.M. and H.A. Marzouk (2005). Comparative studies of using mineral and bio-fertilizers on growth and yield of guava. J. Adv. Agric Res. Fac. Agric. (Saba Basha). Alex. Univ. 10(3): 283-293.

Youssef, A.M., EL-Fouly A.M., Youssef M.S and Mohamedien, S.A.(2001). Effect of using organic fertilizers in ferigation system on yield and fruit quality of tomato. Egypt J. Hort. 28, No.(1): 59-77.

Zaghloul, R.A (2002). Biofertilizeration and organic manuring efficiency on growth and yield of potato plants (Sopanum tubersom, L.). Rec. Technologiesm Agic. Proc. of the Second Congress. Vol. (1): 79-90. 


\section{الملخص العربي}

تأثير استخدام الأسمدة الحيوية والمعدنية على نمو وإثمار أشجار الجوافة صنف بذرى منتخب

$$
\text { وفاء على السيسى، مرفت سرور، إيمان عبد اللاه }
$$

الثمـرة وقطرهـا وكـذلك صـلابة الثمـار بالمعـاملات في كـلا المـوسمين والمعاملة 3، 4 أعطت أعلى سمك للب الثمار في كلا الموسمين. ينما

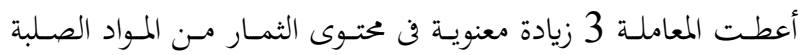

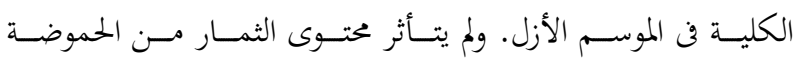

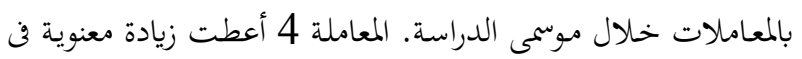
محتوى الثمار من فيتامين C خلال الموسمين. محتوى الأوراق والثمار من العناصر: المعـاملات 2، 3، 4 أعطت أعلى نسبة لعنصـر النيتروجسين في

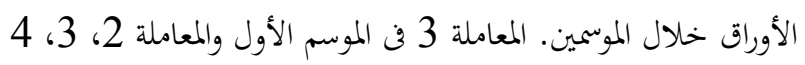

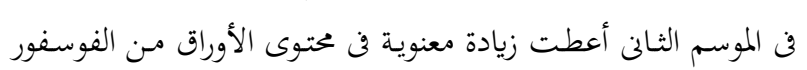

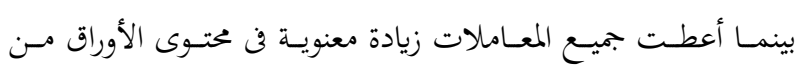

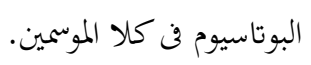

معاملة 3، 4 أعطت زيادة معنوية في محتوى النيتروجين في الثمار بينما لم يتأثر مستوى الفوسفور والبوتاسيوم في الثمار بجميع المعاملات

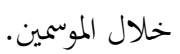
محتوى الأوراق والثمار من الكربوهيدرات الكلية: جميـع المعـاملات أدت إلى زيادة معنويـة في ذلك المختوى خـلال

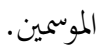

يمكـن التوصية بتخفيض استخدام الآزوت المعـدن بنسبة 50-

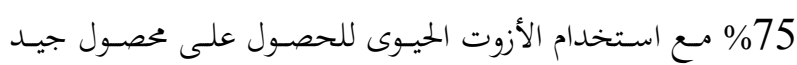
وجودة ثمار مرتفعة كما أنه يوفر المال ويحافظ على البيئة.
أجـرى هـذا البحـث على أشـجار جوافـة بذريـة صـنف بـذرى منتخب عامى 2007، 2008 عمر 12 سنة منزرعة في أرض رملية

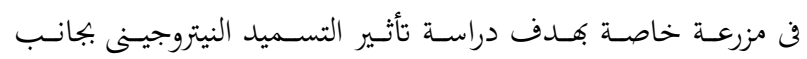

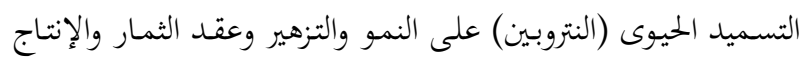

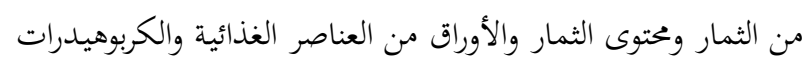
الكلية وكانت النتائج كالآتى: معاملـة 3 (25.25 جـم كبريتـات أمونيـوم + 1 كجــم سـوبر

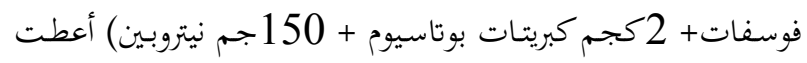

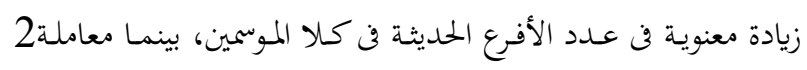

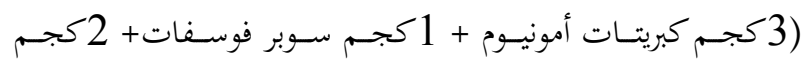

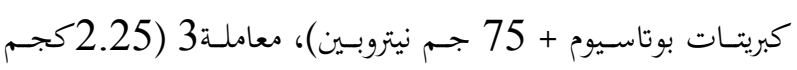

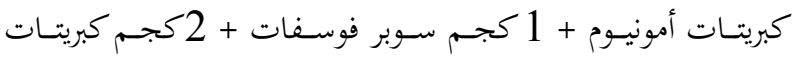

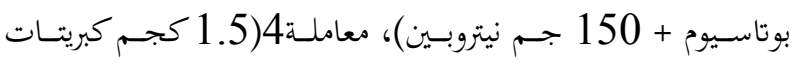

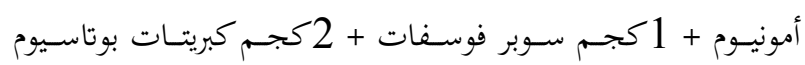

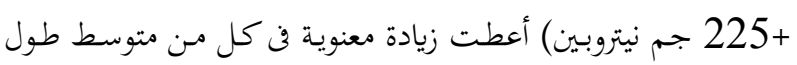

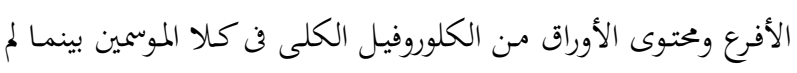

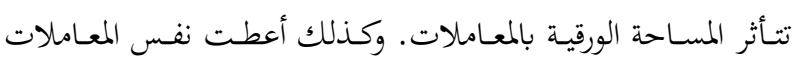

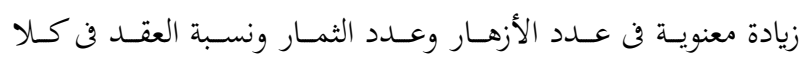
الموسمين. ومعاملة4 أعطت أعلى مصول في كلا الموسمين.

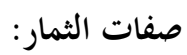
المعـاملات 3، 4، 5 أعطت أعلى وزن للثمـرة في الموسـم الأول فقط ولم يكون هناك أى تأثير في الموسم الثانى بينما لم تتأثر طول في اعلى 